Atlas Journal of Science Education (2011) 1 (2): 43-45

doi: $10.5147 /$ ajse.2011 1.0034

\title{
Reflections of An Undergraduate Teaching Associate
}

\author{
Heather R. Spence
}

Marine and Bioacoustics Programs; Michelle's Earth Foundation, International Research and Outreach; Comision Nacional de Areas Naturales Protegidas, Mexico

Received: December 7, 2010 / Accepted: December 13, 2010

\begin{abstract}
As an undergraduate teaching associate, I collaborated closely with the professor of an honors introductory biology course at George Washington University to help improve the curriculum. Assisting with course revision, implementation, and assessment was a positive, life-changing learning experience, an all-around benefit, and hopefully an inspiration for other collaborations.
\end{abstract}

Key words: Education, Biology, Undergraduate, Teaching Assistant.

\section{Introduction}

In a new approach at George Washington University, l, as an undergraduate, assisted the professor in revising and implementing a renovated curriculum for an introductory biology course. Honors Biology presented unique challenges as it was intended for both science majors and non-majors, and employed a student-centered approach. As a teaching associate who previously took the course, I was involved in all aspects of the course, from the planning, to the implementation and assessment of the revised curriculum. Facilitating students in the course by becoming directly involved in their education, through student-centered teaching methods, and seeking their feedback for assessment, was a rewarding, life changing experience for me, and seemed to be a benefit for all involved: to me, the students, the professor, and even the university. I hope that my positive experience will promote future partnerships between university professors and undergraduate students.

\section{Methods}

\section{Introduction to Honors Biology from a Student Perspective As a} freshman

I took the yearlong Honors Biology course the first time it was offered, in fall 2001 and spring 2002 semesters. The course was designed for students in the University Honors Program, both science and non-science majors. I was considering majoring in Biology, and liked the idea that the course was for a diverse group of motivated students. At an Honors function I met the professor, Dr. Terry L. Hufford, and was excited to find out about his student-centered teaching perspective.

While a number of alternative teaching techniques were used in the course, the format of the class still relied predominantly on lecture, which did not foster sufficient student interaction. This and other aspects of the class did not satisfy the professor and 
students in meeting the goals of the course: to promote understanding of introductory biology material to use critical thinking skills to cultivate the mastery of science as a process, to facilitate improved communication ability and to foster appreciation and interest in biology.

\section{Becoming a Teaching Associate}

At the end of the course, Dr. Hufford asked me if I would be interested in working with him over the summer to revise the course before the fall semester. I was thrilled and honored to be offered this opportunity. My roles that summer were to research alternative teaching techniques, and, working with Dr. Hufford, determine how to approach and plan the course for the following year. Some programs involve students in course planning and creation of assignments (e.g. Beard et. al., 2000), but the fact that I was treated as a colleague in the process seemed a rare opportunity. Dr. Hufford took my input very seriously, on everything from in-class questions for discussion to the time periods of the course.

Since I had just taken the course I had some ideas about what worked and did not work for me when I took it, and also how the other students felt based on my discussions with them. I drew on my previous experiences in the course, teaching, and peer mediation and interviewed faculty members for their input. Helping to plan the course heightened my awareness and appreciation for the work that goes into a course before the teacher ever sets foot in front of the class.

\section{Results and Discussion}

In the following fall and spring, I continued working with Dr. Hufford by assisting with the implementation of the redeveloped course, and assessment of the new teaching methods through research. I was a volunteer, but then was fortunate to receive academic credit, allowing me to be involved in-class as well as out of class. The types of responsibilities given to UTAs in other programs vary, and include everything from laboratory preparation (Saint Louis University, 2005) and grading (University of Delaware, 2010), to facilitating group work (Price, 2006), leading discussion (Wallace, 1974) and helping other TAs (Beard et. al., 2000). My role included helping individual students, facilitating group work, leading class discussion, assisting with further planning and revision, grading presentations, meeting with students to get their honest feedback on the course, and establishing assessment criteria and techniques.

It was very rewarding to help put into place and evaluate the plans made over the summer. The assessment process was an integral part of the course, and allowed for revisions as the course progressed. Being so involved, in both teaching and curriculum assessment, taught me broader lessons as well as specific techniques, that I found myself using for how I approached my other classes and activities.

It seemed my discussions with students made a difference in what they got out of the course, particularly through helping them to understand what was expected from them. I frequently found that students would go ahead, unsure, rather than ask for clarification or look up guidelines. Sometimesencouragement was helpful in stimulating class discussion, or in working things out within a group. Students also came to me with questions or problems, and did not have to worry that their comments would be relayed to Dr. Hufford or their classmates because I let them know at the outset that anything I would pass along would not be associated with them.

This anonymity was very important to the assessment process. During and after the course I interviewed students for their feedback, and they were very candid with me, and provided excellent suggestions and comments. They could also see the results of their input, because Dr. Hufford and I worked to revise the course in progress based on the comments of the class and our own observations. Facilitating the students' ability to freely contribute to the course was perhaps the most rewarding part of my experience.

I continued to assist with the course and its assessment and revision, through its third year. My role, now funded, shifted focus to outside of class, particularly in facilitating group work with the addition of a final group project, and continuing to provide feedback. In fall 2003, I had the honor of presenting our results at the National Association of Biology Teachers conference. After the third year of the course, another professor was not found to continue the course and so it was not offered my senior year. I hope that the work and progress of honors biology will be resumed in the future.

In the meantime, the results were applied to a larger course for non-majors eventually taught by Dr. Hufford. I continued to be involved through the new program of Learning Facilitators. As a coordinator, I was a contact for the learning facilitators and could assist with questions or difficulties. In this role, as in my experiences with the Honors course, some discussion was helpful to clarify the approach taken with the course and what the expectations were. However, the dynamics of this program were very different from the Honors course, and offered less personal involvement and discussion. It was helpful to me to contrast this course with the honors course, and to explore how to modify approaches to fit the larger class and purely non-major perspective.

\section{Conclusions}

My experiences as a teaching associate formed the centerpiece for my undergraduate career. I gained a greater appreciation for, and development of, teaching skills, including organization, curriculum selection, assignment development, and assessment. I also solidified my understanding of basic biology. I learned about assessment research techniques, and I learned from the students in the class. As a student, it was very helpful to gain insight from a teacher's perspective. My experiences working with Dr. Hufford enhanced the tools I could use to approach my courses, personal interactions, and other endeavors. I feel that my preparation for my career and contribution to society was enhanced by my experiences as an undergraduate teaching associate, and hope that others might also benefit from such experiences.

Involving the students more directly in the assessment pro- 
cess really emphasized the effectiveness of the course, making it truly student-centered. I provided not just my own student perspective, but those shared with me through interactions with the students in the class. The course could be geared more appropriately for the particular students, and benefited in the long run from their real-time insight. Active participation of students in the assessment process resulted in more active participation of the students in general. The teaching associate, students, professor, and the university benefit from being able to offer and support such a strengthened course.

\section{References}

Beard D (2000) The Teaching Assistant Program: Some Experiences. Available online at: http://www.cs.brown.edu/courses/ta/ta_experiences/. Accessed November 24, 2010.

Herreid CF (2010) Molly Bergen - Undergraduate Teaching Assistant.
National Center for Case Study Teaching in Science. Available online at: http://ublib.buffalo.edu/libraries/projects/cases/molly. htm. Accessed November 24, 2010.

Oregon State, Biology (2006) Undergraduate Teaching Internship. Available online at: http://oregonstate.edu/instruct/bi213/BI\%20 21 X\%20Internship\%20Application.pdf.Accessed February 7, 2006. Price M (2006) Undergraduates Teaching Experiences. University of Pittsburgh. Available online at: http://www.pitt.edu/ oel/ute/ mprice.htm Accessed February 7, 2006.

Saint Lovis University, Biology Department. (2005). Available online at: http://bio.slu.edu/uteaching.html. Accessed February 7, 2006.

University of Delaware, Department of Biological Sciences. (2010).

Undergraduate Teaching Experience in Biology. Available online at: http://www.udel.edu/bio/ed/undergrad/teaching/. Accessed November 24, 2010.

Wallace RA (1974) An Alternative to Assembly-Line Education: Undergraduate Teaching Assistants. Teaching Sociology 2 (1): 3-14. 